\title{
Information Service and Integration of Maize Markets in Togo
}

\author{
Koffi Yovo \\ Department of Agricultural Economics, Agricultural School, University of Lome, Lome, Togo \\ Email: koffiyovo@yahoo.fr
}

Received 23 January 2015; accepted 9 February 2015; published 12 February 2015

Copyright (C) 2015 by author and Scientific Research Publishing Inc.

This work is licensed under the Creative Commons Attribution International License (CC BY). http://creativecommons.org/licenses/by/4.0/

(c) (i) Open Access

\begin{abstract}
In the framework of liberalization policies, a market information service (SIM) was created in 2008 in Togo. This public service entrusted in collecting and disseminating information about the mercurial of agricultural products aimed to improve the spatial integration of agricultural markets through the development of arbitrage. This paper assesses the impact of price dissemination on the spatial integration of maize markets. To this end, the weekly retail maize prices collected from 13 markets for the period without service (2003-2007) and the period with service (20082012) are considered. The results show that the impact of price dissemination on the spatial integration of maize markets is mitigated. By reference to Lome, neither rural markets nor northern markets have significantly improved their level of long-term and short-term spatial integration. To improve the efficiency of the service, it is necessary to understand the need of the sector's stakeholders in order to revise the current format of the market information service.
\end{abstract}

\section{Keywords}

Market Information Service, Maize Markets Integration

\section{Introduction}

In the past few years, most governments of the developing countries reduced their level of intervention on the market of the agricultural products. Many economists saw a means in this policy of deregulation to improve the effectiveness of the markets whose mechanism was disturbed by the strong public intervention. For this purpose, the market of cereals and specifically that of maize was liberalized in Togo in 1987.

The policy of liberalization is based on the principle that coordination by the market without any direct control of the government is a more effective organization. This policy aims to remove the various dysfunctions to make competition more dynamic in order to ameliorate the efficiency of the markets by facilitating arbitrage. 
The arbitrage is defined as the exchange process between actors on different segments in the market with the objective to draw an advantage of the price differences exceeding the costs of transaction.

In other words, in a market economy, the actors react when they observe opportunities to realize profits with buying in an area where the prices are low and selling in an area where prices are relatively high. If arbitrage is effective, the price differences reflect transaction costs. In this case, the markets are integrated [1].

Thus, the success of trade liberalization policy depends on the force of the agricultural markets to transmit the signals of price from an area to another. This transmission that is as fast as the markets are perfectly integrated. Among the regulatory instruments which improve the process of arbitrage, providing information on the conditions of supply and demand, especially on the evolution of products prices is crucial. This justified the creation in 2008 of the markets information system (SIM) charged to collect and diffuse weekly cereals prices by radio and television. The availability of information allows producers, traders and consumers to rationalize their buying and selling decisions.

So if the SIM in Togo participates primarily to a more comprehensive system of food security, its main objective remains regulation of agricultural markets by information. Yovo and Homevoh [2] had already highlighted the role of information in the agricultural products trade is particularly important in Togo because of the great variability in agricultural prices due to the problem of price transmission between urban and rural markets and the problem of market segmentation between the northern and the southern part of the country. In fact, with a stretched form, the country makes $600 \mathrm{~km}$ of length and only $26 \mathrm{~km}$ of east-west maximum width.

This paper analyzes the impact of the diffusion of the maize prices on the spatial integration of cereal markets in Togo. In fact, maize is the main food stuff among cereals marketed in Togo. More precisely, the article tries to answer the following questions: did the weekly diffusion of information on the maize prices improve integration of the urban markets and rural markets and between northern markets and southern markets? To respond this question, the article begins with an analysis of the role of information in the functioning of the market (section 2). Section 3 presents the methodology and data used to analyze the impact of SIM on the markets integration. Section 4 discusses the results, draws a conclusion and gives a direction for future research.

\section{Literature Review}

\subsection{Theorical Framework}

The modern economic theory places information in the center of the performance of the markets. In the theory of the competitive Walrasian general equilibrium, information concerning the scarcity of the resources is accessible to all the economic agents, this facilitates the optimal allocation of the resources. Thus, the price summarizes information. A high price indicates too short supply or too long demand, and vice versa. In other words, the equilibrium price transmits information to the economic agents and plays to some extent the part in signals of the market [3]-[6]. Grossman and Stiglitz [7] criticized the models of Greene and Lucas, and highlighted that if the price transmitted all information, it was not necessary to buy information or to diffuse it. But the fact is that in reality the markets often operate with asymmetric information, as is the case in developing countries. However, one of the lessons of the economy of information is that in an environment where information is asymmetric, the agents manage a risky situation which hampers the functioning of markets [8]. Two types of risk are generally quoted in the literature: the anti-selection also called adverse selection is a situation where the market is disturbed by the fact that a party knows better the characteristics of the goods exchanged at the time of signature of the contract and moral hazard is a situation in which one party called the principal cannot control the action of the other called agent or does not have the means to evaluate his opportunity.

When buyers imperfectly observe the quality of goods they want to buy, sellers have an incentive to overestimate the quality of their products and sell them at the highest possible price. The purchasers cannot thus trust the declarations of the sellers, nor to deduce that a high price means a good quality. In such situation, the sellers of goods of good quality which are worth indeed a high price, can have no possibility to sell their product at their true price insofar as the buyers doubt his quality. The price is any more a perfect signal of the value of the good and can no longer play its role in information.

Under these conditions, the competitive market cannot function effectively any more. The agent victim of a lack of information is likely to select a product which does not correspond to the displayed price, or requires a price so low that the good products are withdrawn from the market. It is what Akerlof [9] reveals for the market of the insurances where he shows that the "bad products drive out the goods". So let it do can have disastrous 
consequences: elimination of the good products, reduction or absence of exchange.

With regard to cereal markets, the existence of asymmetric information between buyers and sellers may provoke problems such as adverse selection and modify the nature of their transaction, or more generally, the process of arbitrage.

Asymmetric information about prices, quantities and quality is a barrier to trade between urban markets and rural markets as it hampers producers and consumers to rationalize their buying and selling decisions. This makes exchanges unequal. Consequently, the availability and accessibility of information leads to the reduction of transaction costs and oligopolistic markets which are often based on possibility for certain traders to detain specific information. Many failures in the arbitrage process among different markets can be explained by the concentration of information in the hand of these traders. In order to ameliorate the circulation of information, information services of agricultural markets have been promoted in several countries in transition [10].

The function of the SIM is to collect information on the exchanges and to diffuse them among the public actors (State) and especially among private actors (producers, traders and consumers) for a better decision making. Market information can be regarded as a public good, particularly where there are numerous small farmers who are unable to pay for information.

For [10]-[12], transparency in agricultural markets results in the following effects:

- The farmers who receive the proper production incentives will adjust their production accordingly and will seize on market opportunities;

- Lower transaction costs result in lower consumer prices, higher output prices;

- Information can improve the bargaining position of the weaker participants in a marketing system who are usually the smallholder farmers;

- Easier access to markets for small producers result in increased marketable surplus;

- Competition is enhanced, resulting in fair prices and equity for all participants;

- Market information signals profit opportunities and thus creates incentives for market participants;

- Seasonal and erratic price variations will be reduced and arbitrage among markets will take place, thereby reducing price differentials between markets.

- In completely transparent and efficient markets, price differentials reflect only transaction costs (mainly transport costs) between markets;

- Overall risk is reduced for all market participants, resulting in more stable markets,

- Improved long term planning and investment decisions;

- Reduction of trader's opportunism and entry barriers and consequently the decline of actors rents.

- Improved government regulation of markets: better agricultural and marketing policies and public investments as governments will be adequately informed about market conditions and performance.

\subsection{Empirical Framework}

The publications those having addressed the real impact of SIM, especially in Africa are few. A study of 120 countries was notably conducted by FAO in the mid-90s [11]. The study found a low impact SIM called "first generation". According to the author, this impact would be small because the information provided is little used by the actors because:

- A poor quality and poor dissemination of information;

- The lack of usability of actors (credit, transportation-related contracts with traders, etc...);

- Incompleteness of information (product quality, product substitutes, public action);

- The fact that the information was already available (through the dealer network, the informal system)

According to Egg [11], the low impact of SIM of "first generation" can be explained either by technical weaknesses or by poor articulation with the SIM communication systems embodied in the markets themselves.

Bassolet and Lutz [1] also concluded the mitigated effect of the information system on the integration of sorghum markets in Burkina Faso. The authors showed that the prices issued by the information service were not determinants for the arbitrage of cereals traders. According to the authors' opinion, this is due to the quasigeneral ignorance about the day of price diffusion on the radio.

However, some encouraging impact of SIM on the markets functioning, or at least on the process of producer's decision making were reported in Mali [13], Ghana, Uganda, Indonesia [14].

The latter works are rather periodic reports than rigorous studies. These impacts are thus dubitative. Only an 
econometric assessment would be an objective, quantitative evaluation to draw a clear conclusion. This was what Bassolet and Lutz [1] did for Burkina Faso. Indeed, they used an econometric approach based on co-integration technique.

Despite their popularity, co-integration models have been sharply criticized as tools to assess markets integration. Indeed since 1996, some economists have questioned the relevance of co-integration models as dynamic method to analysis market integration. They show that where trade between two markets is bidirectional, transaction costs are high and non-stationary, results from the co-integration techniques are biased and lead to erroneous conclusions. The main defenders of this school are: [15]-[20]. According to Mc New [17], linearity of bivariate was inappropriate to test the integration of markets. Mc New and Fackler [18] showed that the price series on two integrated markets were not necessarily co-integrated.

Barrett [15] and Baulch [19] have had the merit of clarifying the problem by presenting a hierarchical classification of market integration analysis methods based on the nature of the data. The methods called level I which only used data on prices. These methods are described as significantly more likely to specification errors. Level II methods combine data on prices and transaction costs. Level III methods combine data on prices, transaction costs and trade flows. They provide more flexibility and possibility of inference. For example, the method "Parity bounds model”, PBM, introduced by Baulch [19] using both price data and transaction costs were estimated by maximum likelihood. PBM's approach was adapted by $\mathrm{Li}$ and Barett [20] in a method called "Method Li-Barett” (LBM), which distinguished between market integration and equilibrium of the markets. This method used prices data, transaction costs and trade flows.

The analysis of the integration of maize markets with the methods of Level II and III is virtually impossible in the context of the present study because of the unavailability of secondary data on transaction costs and trade volumes among markets. In contrast, the level I method based only on the price series is still possible on the condition to specify the co-integration model correctly (see [1] [2] [24]-[30]).

\section{Methodology}

\subsection{The Model}

To assess the impact of the diffusion of agricultural products mercurial on the functioning of the maize market, the model of Ravallion [21] is found appropriate to test thirteen markets integration. Ravallion model is a model of "autoregressive distributed lag”. His econometric specification is as follows:

$$
P_{i t}=\sum_{j=1}^{n} a_{i j} P_{i t-j}+\sum_{j=0}^{n} b_{1 j} R_{t-j}+c_{i} X_{i t}+e_{i t}
$$

$R$ is the price of the reference market and it is supposed to influence the price $P_{i}$ of the dependent markets $i$, $X_{i}$ represents a vector with other influences on the dependent markets $i, a_{i j}, b_{1 j}$ and $c_{i}$, are parameters, $e_{i t}$ expresses the residual, $t$ indicates time and $j$ is a lag.

Ravallion model will be estimated following the methodological framework suggested by Dercon [24]. It consists in estimating the Ravallion model in five steps.

The first step determines the order of integration of the variables analyzed. This step determines the number of times that a variable must be differentiated to become stationary. The test "Augmented Dickey Fuller" (ADF) is suitable for determining the order of integration.

The second step tests the hypothesis of co-integration between price series $P_{t}$ and $R_{t}$. The two-step procedure of Engle and Granger [23] is generally recommended. However, in this study, we prefer the one-step method of Hendry in order to reduce bias risk [22]. The model is specified as follows:

Considering:

$$
P_{t}=\alpha R_{t}+e_{t}
$$

With

$$
e_{t}=\rho e_{t-1}+\varepsilon_{t}, \quad \varepsilon \sim I(0)
$$

Substituting (3) in (2), it follows:

$$
P_{t}=\alpha R_{t}+\rho e_{t-1}+\varepsilon_{t}
$$

And 


$$
P_{t-1}=\alpha R_{t-1}+e_{t-1}
$$

By taking Ptand Rtin difference,

$$
\Delta P_{t}=\alpha \Delta R_{t}+(\rho-1) e_{t-1}+\varepsilon_{t}
$$

Substituting $e_{t-1}$ by it expression, it follows

$$
\Delta P_{t}=\beta+\alpha \Delta R_{t}+(\rho-1) P_{t-1}-\alpha(\rho-1) R_{t-1}+\varepsilon_{t}
$$

$P_{t}$ and $R_{t}$ are cointegrated if and only if:

$$
-1<\rho<1 \Leftrightarrow-2<\rho-1<0
$$

To assess the effect of the mercurial dissemination, we consider two periods: period 1, the period without mercurial dissemination and period 2, the period with the mercurial dissemination. For both periods 1 and 2, Equation (7) can be written respectively:

$$
\begin{aligned}
& \Delta P_{t}=\beta_{1}+\alpha_{1} \Delta R_{t}+\left(\rho_{1}-1\right) P_{t-1}-\alpha_{1}\left(\rho_{1}-1\right) R_{t-1}+\varepsilon_{t} \\
& \Delta P_{t}=\beta_{2}+\alpha_{2} \Delta R_{t}+\left(\rho_{2}-1\right) P_{t-1}-\alpha_{2}\left(\rho_{2}-1\right) R_{t-1}+\varepsilon_{t}
\end{aligned}
$$

with $\beta_{1} \neq \beta_{2} ; \quad \alpha_{1} \neq \alpha_{2} ; \quad \rho_{1} \neq \rho_{2}$

In order to capture the effect of the mercurial dissemination, we introduce a dummy variable $D$ (dummy) in the model.

$D=1$ for the period with mercurial dissemination

$D=0$ for the period without mercurial dissemination

$$
\begin{aligned}
& \beta_{2}=\beta_{1}+D \delta_{\beta} \\
& \alpha_{2}=\alpha_{1}+D \delta_{\alpha} \\
& \rho_{2}=\rho_{1}+D \delta_{\rho}
\end{aligned}
$$

Then Equation (9) becomes:

$$
\Delta P_{t}=\beta_{1}+D \delta_{\beta_{1}}+\alpha_{1} \Delta R_{t}+D \delta_{\alpha} \Delta R_{t}+\left(\rho_{1}-1\right) P_{t-1}+D \delta_{\rho} P_{t-1}-\alpha_{1}\left(\rho_{1}-1\right) R_{t-1}-D \theta R_{t-1}+\varepsilon_{t}
$$

with $\theta=\left(\alpha_{1}+\delta_{\alpha}\right) \delta_{\rho}+\delta_{\alpha}\left(\rho_{1}-1\right)$.

The estimation of Equation (10) allows to test the co-integration of prices series and to assess the impact of mercurial diffusion on the long term market integration as follows:

Test of co-integration of prices series without mercurial dissemination

Ho: $\rho_{1}-1=0$

Test of co-integration of prices series with mercurial dissemination

Ho: $\rho_{1}+\delta_{\rho}-1=0$

Test of dissemination effect on the long term market integration

Ho: $\delta_{\beta}=0, \delta_{\alpha}=0$ et $\delta_{\rho}=0$

The third step concerns Granger causality test, which is interpreted as evidence on the direction of price adjustment. Theoretically, in the market network, the reference market should influence all other dependent markets. In other words, for this test the null hypothesis (Ho) should be rejected. The Granger causality test is applied to the reduced form of Ravallion model by including the error correction mechanism (ECM).

If prices are co-integrated, then the series of the Equation (11) are stationary and the standard distribution of $F$ can be used to interpret the results of causality test as follows:

$\Delta P_{i t}=\gamma_{i}+D \delta_{\gamma_{i}}+\sum_{j=1}^{n-1} \mu_{i j} \Delta P_{i, t-j}+\sum_{j=1}^{n-1} D \delta_{\mu_{i j}} \Delta P_{i, t-j}+\sum_{j=1}^{n-1} \eta_{1, j} \Delta R_{1, t-j}+\sum_{j=1}^{n-1} D \delta_{\eta_{i j}} \Delta R_{1, t-j}-\theta_{i} \mathrm{MCE}_{t-1}-D \delta_{\theta_{\mathrm{i}} \mathrm{MCE} t-1}+v_{i t}$

where:

$$
\mathrm{MCE}_{t-1}=P_{i, t-1}-\alpha R_{1, t-1}
$$

Causality Test: Ho: $\eta_{1 j}=\theta_{i}=0$ 
In compliance with the theorem of Engle-Granger representation [23], when two variables are co-integrated of order 1, the best representation of their short-term dynamics is the error correction model (ECM). Equation (12) below applied to the structural form of Ravallion model depicts the short-term price adjustment process. $\left(P_{t-1}-\alpha R_{t-1}\right)$ is the error term and $\lambda$ is the coefficient of the error term. More this coefficient is low, less the speed of adjustment of prices is fast. Thus, when $\lambda$ is close to 1 , the system move quickly to its equilibrium.

$\Delta P_{i t}=\psi_{i}+D \delta_{\psi_{i}}+\sum_{j=1}^{n-1} a_{i j} \Delta P_{i, t-j}+\sum_{j=1}^{n-1} D \delta_{a_{i j}} \Delta P_{i, t-j}+\sum_{j=0}^{n-1} \beta_{1, j} \Delta R_{1, t-j}+\sum_{j=0}^{n-1} D \delta_{\beta_{1, j}} \Delta R_{1, t-j}-\lambda_{i} \mathrm{MCE}_{t-1}-D \delta_{\lambda_{i}} \mathrm{MCE}_{t-1}+e_{i t}$

This equation can be estimated with ordinary least squares (OLS) if $\Delta R_{1 t}$ is weakly exogenous, condition which is not met when markets are interdependent.

The fourth step of the analysis then consists in testing previously the exogeneity of $\Delta R_{1 t}$ before estimating Equation (12) by the OLS. It checks whether this variable is correlated with the residues of the model. This step is not a direct test of weak exogeneity but rather a test of the bias involved if OLS is applied despite the absence of weak exogeneity [24]. The test will be performed as follows: $\Delta R_{1 t}$ will be estimated in an auxiliary regression (13) using only weakly exogenous (lagged) variables $\left(\Delta R_{1, t-n}, \Delta P_{t-n}\right)$ and the relevant error correction term $\left(P_{t-1}-\alpha R_{1, t-1}\right)$. The residuals of this equation are included as an exogenous variable (Resid) in Equation (14). If the bias is insignificant, the coefficient $\left(\phi_{i}\right)$ tends to zero (see [24] [29]).

$$
\begin{aligned}
\Delta R_{1 t}= & \omega_{i}+D \delta_{\omega_{i}}+\sum_{j=1}^{n-1} \pi_{i j} \Delta P_{i, t-j}+\sum_{j=1}^{n-1} D \delta_{\pi_{i j}} \Delta P_{i, t-j}+\sum_{j=1}^{n-1} \psi_{1, j} \Delta R_{1, t-j}+\sum_{j=1}^{n-1} D \delta_{\psi_{1, j}} \Delta R_{1, t-j}-\zeta_{i} \mathrm{MCE}_{t-1}-D \delta_{\zeta_{i} \mathrm{MCE}_{t-1}} \\
& +\operatorname{Resid}_{i t} . \\
\Delta P_{i t}= & \varphi_{i}+D \delta_{\varphi_{i}}+\sum_{j=1}^{n-1} \Omega_{i, j} \Delta P_{i, t-j}+\sum_{j=1}^{n-1} D \delta_{\Omega_{i, j}} \Delta P_{i, t-j}+\sum_{j=1}^{n-1} \sigma_{i, j} \Delta R_{1, t-j}+\sum_{j=1}^{n-1} D \delta_{\sigma_{i, j}} \Delta R_{1, t-j}+\phi_{i} \operatorname{Resid}_{i t}-\tau_{i} \mathrm{MCE}_{t-1} \\
& -D \delta_{\tau_{i} \mathrm{MCE} t-1}+\omega_{i t} .
\end{aligned}
$$

The exogeneity test once conclusive the fifth step is to test the integration of short-term using Equation (12). It simulates the dynamics of the short term and allows verifying if the reference market signals are transmitted immediately to the dependent markets. This is tested by the simultaneous hypothesis $\mathrm{H}_{0}$ :

Ho: $\lambda=\beta_{10}=1$ and $\alpha_{i 1}=\cdots=\alpha_{i n}=\beta_{11}=\cdots=\beta_{1 n}=0$

The dynamic analysis assesses the degree and speed of adjustment of prices through the dynamic multipliers of the ECM. These are interpreted as the effect of change in price $P_{i t}$ subsequent to change in an exogenous variable [25]. In Equation (13), the cumulative effect of a shock resulting from price change in the reference market $\left(R_{1}\right)$ on the price in the dependent market $P_{i t}$ after $k$ periods is given by:

$$
\mu_{k}^{i, 1}=\sum_{h=0}^{k} \frac{\partial E\left[P_{i}(t+h)\right]}{\partial R_{1}(t)}
$$

The full adjustment of the dynamic process described by the MCE is given by the dynamic multiplier and long term is:

$$
\mu_{\infty}^{i, 1}=\lim _{k \rightarrow \infty} \mu_{k}^{i, 1}
$$

Like [25] composite index represented by the ratio between the degree and the speed of price adjustment can be generated. These indexes rank between 0 and 1 , with 0 indicating a minimal integration and 1 a maximum integration.

\subsection{Data}

The data used are nominal ${ }^{1}$, weekly retail maize prices for the periods from January 2003 to December 2007 and February 2008 to December 2012. These time series were extracted from the base price data of ANSAT (National Agency for Food Security in Togo). Since 1998, ANSAT have collected the prices of some agricultural products

${ }^{1}$ We use nominal instead of real prices because traders' arbitrage is not based on real but on nominal prices. It may be the reason why many of the authors reviewed use nominal prices (see [1] [2] [24] [25] [30]). Moreover, weekly inflation of cereals prices was not a concern that can affect significantly the efficiency of traders' arbitrage during the most period of study. 
in particular cereals throughout the territory but they were not disseminated until 2008. The mercurial collected was made available to policy makers (Ministry of Economy, Ministry of Agriculture) for decision making. Since February 2008, the mercurial is broadcast every Wednesday through national television.

In total, 13 markets are selected according to geographical, economic criteria and availability of data.

The urban markets are represented by head of each economic region: Lome, Atakpame, Sokode, Kara and Dapaong; Lome, the capital, has the most important and regular deficits in maize despite the convergence of maize produced in the others regions. This is due to the concentration of the population whose main food staple is maize. Atakpame has the most important and regular surplus. It is the principal assembly and storage center for the country's cereals. This market provisions others urban markets through the wholesalers coming from the southern and northern regions of the country. The other cities have fair and irregular surplus. Because of these reasons, Lome and Atakpame are chosen as potential reference markets.

The dependent rural markets are markets in production zones. They are selected on the basis of the importance of the maize volume transaction they established with references markets as well as the availability of price series. They are Cinkasse and Gando in Savannas region, Ketao and Kabouin Kara region, Tchamba and Sotouboua in the central region, Anie and Amlame in Plateaux region (see the map of markets localization).

\section{Results and Discussion}

The objective of this work is to analyze the process of integration of maize markets in Togo in order to understand how it was affected by the diffusion of prices. Results is analyzed in accordance with the methodology in five steps namely the unit root test, co-integration test, the causality test , the test of endogeneity and short-term integration test .

\subsection{Unit Root Test on the Prices Series}

Table 1 shows the results of the unit root tests. The ADF test and Perron test, which takes into account the potential change in the trend after the 261th observation, do not reject the existence of a unit root in the series taken in level. Price series (see graphics in Annex 1) are not stationary. However, the ADF test for the price series in their first difference shows that the t-statistic is different from zero at the $1 \%$. Price series are stationary in their first differences where they are integrated in order 1 (I1).

\section{Table 1. Result of Unit root test.}

\begin{tabular}{cccc}
\hline & Level: ADF statistics & Level: Perron test & First difference: ADF statistics \\
\hline Lome & $-1.47[2]$ & $-1.33[1]$ & $-11.30[1]$ \\
Atakpame & $-1.95[3]$ & $-2.16[3]$ & $-12.42[1]$ \\
Sokode & $-2.11[1]$ & $-1.29[2]$ & $-15.23[0]$ \\
Kara & $-2.09[4]$ & $-1.30[4]$ & $-10.02[1]$ \\
Dapaong & $-2.00[4]$ & $-1.88[4]$ & $-12.22[1]$ \\
Amlame & $-1.48[2]$ & $-3.14[2]$ & $-9.80[1]$ \\
Anie & $-2.24[5]$ & $-1.31[2]$ & $-13.05[1]$ \\
Tchamba & $-1.70[3]$ & $-3.01[4]$ & $-8.36[1]$ \\
Sotouboua & $-1.38[5]$ & $-2.12[3]$ & $-7.22[1]$ \\
Kabou & $-1.91[4]$ & $-2.11[2]$ & $-10.51[1]$ \\
Ketao & $-1.60[4]$ & $-2.901[2]$ & $-6.92[1]$ \\
Gando & $-2.51[1]$ & $-2.23[1]$ & $-21.26[0]$ \\
Cinkassé & $-1.20[2]$ & $-1.31[2]$ & $-13.05[1]$ \\
\hline
\end{tabular}

Source: Author's calculation based on data from ANSAT; Values in brackets are the numbers of lags necessary to obtain white noise (no autocorrelated residuals). The critical Mackinnon values of ADF test are: $(-3.52)$ for $1 \%$; $(-2.94)$ for $5 \%$; $(-2.68)$ for $10 \%$. The critical values for Perron test are: $(-5.07)$ for $1 \%$ and $(-4.22)$ for $5 \%$. 


\subsection{Co-integration Tests on the Prices Series}

The price series are all being integrated of order 1 , the second step is to check the existence of a long-term process of integration among the price series in different markets. To do this, we consider the radial structure of markets assuming Lome as the reference market. The co-integration test using the method of Hendry in one step gives the results shown in Table 2. It appears that when considering Lome as the reference market, tests show that all markets are co-integrated at $5 \%$ regardless price dissemination. Indeed, the values $\delta_{\beta}, \delta_{\alpha}$, $\delta_{\rho}$, which measure changes in the coefficients of co-integration, are not significant at 5\% except in three cases: Dapaong, Anie and Cinkasse markets. The changes here can be interpreted as an improvement in the level of integration of these markets. However, at $1 \%$, no change is noticeable.

When considering Atakpame as the reference market, the results of co-integration tests reported in Table 3 are similar to what is found for Lome. In fact, regardless the dissemination, all the markets except Ketao and Kabou are integrated to Atakpame. The values $\delta_{\beta}, \delta_{\alpha}, \delta_{\rho}$, which measure changes in the coefficients of co-integration, are not significant at $10 \%$ except in three case: Amlame, Tchamba and Cinkasse markets.

It is instructive to note that Cinkasse market in both cases has improved its level of integration. This could be explained by the fact that cross-border traders from Cinkasse which is a cross-border market use price's information to improve their decision making. Before prices dissemination, the arbitrage process may be difficult due to the distance making more than $600 \mathrm{~km}$ from Lome.

As regard the results, it arises that the prices diffusion service has a marginal effect on long run markets integration. This suggests that the current mode of diffusion of the prices does not affect significantly the process of private trader's arbitrage.

This result remains, however, very general, and as regards recommendation of food policy its implementation will be very limited because of some concerns: which is the level of markets integration? Which is the direc-

Table 2. Test for co-integration with Lome as reference market.

\begin{tabular}{|c|c|c|c|c|c|}
\hline \multirow{2}{*}{ Markets } & \multirow{2}{*}{$\begin{array}{c}\text { Coint coeff } \\
\text { without dissemination } \\
\rho_{1}-1\end{array}$} & \multirow{2}{*}{$\begin{array}{c}\text { Coint coeff } \\
\text { with dissemination: } \\
\qquad \rho_{1}+\delta_{\rho}-1\end{array}$} & \multicolumn{3}{|c|}{ Dissemination effect } \\
\hline & & & $\delta_{\beta}$ & $\delta_{\alpha}$ & $\delta_{\rho}$ \\
\hline Atakpame & $\begin{array}{c}-0.65^{* * *} \\
(0.00)\end{array}$ & $\begin{array}{c}-0.51^{* *} \\
(0.01)\end{array}$ & $\begin{array}{c}1.05 \\
(0.25)\end{array}$ & $\begin{array}{l}-0.20 \\
(0.11)\end{array}$ & $\begin{array}{c}0.17 \\
(0.20)\end{array}$ \\
\hline Sokode & $\begin{array}{l}-0.38^{* *} \\
(0.00)\end{array}$ & $\begin{array}{c}-0.39^{* * * *} \\
(0.00)\end{array}$ & $\begin{array}{l}0.75 \\
0.45)\end{array}$ & $\begin{array}{c}0.49 \\
(0.28)\end{array}$ & $\begin{array}{l}-0.03 \\
(0.23)\end{array}$ \\
\hline Kara & $\begin{array}{l}-0.50^{* *} \\
(0.04)\end{array}$ & $\begin{array}{l}-0.51^{* *} \\
(0.03)\end{array}$ & $\begin{array}{c}0.30 \\
(0.21)\end{array}$ & $\begin{array}{l}-0.06 \\
(0.76)\end{array}$ & $\begin{array}{c}0.04 \\
(0.24)\end{array}$ \\
\hline Dapaong & $\begin{array}{l}-0.18^{* *} \\
(0.04)\end{array}$ & $\begin{array}{c}-0.39^{* * * *} \\
(0.01)\end{array}$ & $\begin{array}{l}0.08^{* *} \\
(0.02)\end{array}$ & $\begin{array}{l}0.21^{* *} \\
(0.04)\end{array}$ & $\begin{array}{l}-0.14 \\
(0.90)\end{array}$ \\
\hline Amlame & $\begin{array}{c}-0.15^{* * *} \\
(0.00)\end{array}$ & $\begin{array}{l}-0.34^{* *} \\
(0.03)\end{array}$ & $\begin{array}{l}-0.12 \\
(0.34)\end{array}$ & $\begin{array}{l}-0.07 \\
(0.78)\end{array}$ & $\begin{array}{l}-0.20 \\
(0.84)\end{array}$ \\
\hline Anie & $\begin{array}{l}-0.70^{* *} \\
(0.03)\end{array}$ & $\begin{array}{c}-0.88^{* * *} \\
(0.00)\end{array}$ & $\begin{array}{l}-0.24^{* *} \\
(0.02)\end{array}$ & $\begin{array}{l}0.08^{* *} \\
(0.03)\end{array}$ & $\begin{array}{l}-0.07 \\
(0.14)\end{array}$ \\
\hline Tchamba & $\begin{array}{l}-0.97^{* * *} \\
(0.00)\end{array}$ & $\begin{array}{l}-0.80^{* *} \\
(0.04)\end{array}$ & $\begin{array}{c}0.36 \\
(0.50)\end{array}$ & $\begin{array}{l}-0.02 \\
(0.20)\end{array}$ & $\begin{array}{l}-0.16 \\
(0.22)\end{array}$ \\
\hline Sotouboua & $\begin{array}{l}-0.60^{* * *} \\
(0.03)\end{array}$ & $\begin{array}{c}-0.54^{* * *} \\
(0.00)\end{array}$ & $\begin{array}{c}0.24 \\
(0.35)\end{array}$ & $\begin{array}{l}-0.16 \\
(0.27)\end{array}$ & $\begin{array}{l}-0.22 \\
(0.80)\end{array}$ \\
\hline Kabou & $\begin{array}{c}-0.25^{* * *} \\
(0.00)\end{array}$ & $\begin{array}{c}-0.16^{* * *} \\
(0.00)\end{array}$ & $\begin{array}{l}-1.32 \\
(0.55)\end{array}$ & $\begin{array}{l}-0.09 \\
(0.56)\end{array}$ & $\begin{array}{c}0.08 \\
(0.65)\end{array}$ \\
\hline Ketao & $\begin{array}{c}-0.05^{* * *} \\
(0.00)\end{array}$ & $\begin{array}{l}-0.01^{* *} \\
(0.03)\end{array}$ & $\begin{array}{c}0.70 \\
(0.30)\end{array}$ & $\begin{array}{c}0.42 \\
(0.19)\end{array}$ & $\begin{array}{c}0.03 \\
(0.10)\end{array}$ \\
\hline Gando & $\begin{array}{c}-0.23^{* * *} \\
(0.00)\end{array}$ & $\begin{array}{c}-0.26^{* *} \\
(0.04)\end{array}$ & $\begin{array}{l}-3.10 \\
(0.73)\end{array}$ & $\begin{array}{l}-0.41 \\
(0.33)\end{array}$ & $\begin{array}{c}0.07 \\
(0.49)\end{array}$ \\
\hline Cinkasse & $\begin{array}{c}-0.26^{*} * \\
(0.02)\end{array}$ & $\begin{array}{c}-0.85^{* *} \\
(0.01)\end{array}$ & $\begin{array}{c}2.12 \\
(0.13)\end{array}$ & $\begin{array}{l}0.07^{* *} \\
(0.03)\end{array}$ & $\begin{array}{l}-0.05 \\
(0.24)\end{array}$ \\
\hline
\end{tabular}

Source: Author's calculation based on data from ANSAT; Numbers in parentheses are p-values; ${ }^{* * *}$ : significant at $1 \%{ }^{* *}{ }^{*}$ significant at $5 \%$; ${ }^{*}$ : significant at $10 \%$. 
Table 3. Test for co-integration with Atakpame as reference market.

\begin{tabular}{|c|c|c|c|c|c|}
\hline Markets & $\begin{array}{c}\text { Coint coeff } \\
\text { without dissemination: } \\
\qquad \rho_{1}-1\end{array}$ & $\begin{array}{l}\text { Coint coeff } \\
\text { with dissemination: } \\
\rho_{1}+\delta_{\rho}-1\end{array}$ & $\delta_{\beta}$ & ation effe & $\delta_{\rho}$ \\
\hline Lome & $\begin{array}{l}-0.68^{* * *} \\
(0.00)\end{array}$ & $\begin{array}{l}-0.67^{* *} \\
(0.02)\end{array}$ & $\begin{array}{l}-4.25^{* *} \\
(0.03)\end{array}$ & $\begin{array}{l}-0.32 \\
(0.20)\end{array}$ & $\begin{array}{c}0.01 \\
(0.90)\end{array}$ \\
\hline Sokode & $\begin{array}{l}-0.36^{* * *} \\
(0.00)\end{array}$ & $\begin{array}{l}-0.43^{* * *} \\
(0.00)\end{array}$ & $\begin{array}{c}0.44 \\
(0.24)\end{array}$ & $\begin{array}{l}-0.02 \\
(0.49)\end{array}$ & $\begin{array}{l}-0.07 \\
(0.21)\end{array}$ \\
\hline Kara & $\begin{array}{l}-0.52^{* * *} \\
(0.00)\end{array}$ & $\begin{array}{l}-0.47^{* *} \\
(0.01)\end{array}$ & $\begin{array}{l}1.70 . \\
(0.11)\end{array}$ & $\begin{array}{l}-0.05 \\
(0.76)\end{array}$ & $\begin{array}{c}0.05 \\
(0.44)\end{array}$ \\
\hline Dapaong & $\begin{array}{l}-0.38^{* * *} \\
(0.02)\end{array}$ & $\begin{array}{l}-0.62^{* * *} \\
(0.02)\end{array}$ & $\begin{array}{c}0.08 \\
(0.05)\end{array}$ & $\begin{array}{c}0.12 \\
(0.04)\end{array}$ & $\begin{array}{l}-0.24 \\
(0.85)\end{array}$ \\
\hline Amlame & $\begin{array}{c}-0.14^{* * * *} \\
(0.00)\end{array}$ & $\begin{array}{c}-0.45^{* *} \\
(0.03)\end{array}$ & $\begin{array}{l}-0.12 \\
(0.34)\end{array}$ & $\begin{array}{c}-0.07^{* *} \\
(0.02)\end{array}$ & $\begin{array}{l}-0.31 \\
(0.34)\end{array}$ \\
\hline Anie & $\begin{array}{l}-0.80^{*} \\
(0.06)\end{array}$ & $\begin{array}{l}-0.95^{*} \\
(0.07)\end{array}$ & $\begin{array}{l}-3.70 \\
(0.14)\end{array}$ & $\begin{array}{l}-0.40 \\
(0.11)\end{array}$ & $\begin{array}{l}-0.15 \\
(0.30)\end{array}$ \\
\hline Tchamba & $\begin{array}{l}-0.42 \\
(0.30)\end{array}$ & $\begin{array}{l}-0.54^{* *} \\
(0.04)\end{array}$ & $\begin{array}{c}0.22 \\
(0.45)\end{array}$ & $\begin{array}{c}-0.02^{* * *} \\
(0.04)\end{array}$ & $\begin{array}{c}-0.12^{* *} \\
(0.01)\end{array}$ \\
\hline Sotoboua & $\begin{array}{l}-0.60^{* *} \\
(0.03)\end{array}$ & $\begin{array}{l}-0.69^{*} \\
(0.05)\end{array}$ & $\begin{array}{c}0.42 \\
(0.15)\end{array}$ & $\begin{array}{l}-0.16 \\
(0.27)\end{array}$ & $\begin{array}{l}-0.09 \\
(0.52)\end{array}$ \\
\hline Kabou & $\begin{array}{l}-0.49 \\
(0.75)\end{array}$ & $\begin{array}{l}-0.41 \\
(0.25)\end{array}$ & $\begin{array}{l}-1.05 \\
(0.50)\end{array}$ & $\begin{array}{l}-0.09 \\
(0.16)\end{array}$ & $\begin{array}{c}0.08 \\
(0.55)\end{array}$ \\
\hline Ketao & $\begin{array}{l}-0.05 \\
(0.12)\end{array}$ & $\begin{array}{l}-0.11) \\
(0.03)\end{array}$ & $\begin{array}{c}2.33 \\
(0.30)\end{array}$ & $\begin{array}{c}0.42 \\
(0.19)\end{array}$ & $\begin{array}{c}0.03 \\
(0.10)\end{array}$ \\
\hline Gando & $\begin{array}{l}-0.65^{*} \\
(0.07)\end{array}$ & $\begin{array}{l}-0.08^{*} \\
(0.06)\end{array}$ & $\begin{array}{l}-3.10 \\
(0.10)\end{array}$ & $\begin{array}{l}-0.41 \\
(0.33)\end{array}$ & $\begin{array}{l}-0.57 \\
(0.18)\end{array}$ \\
\hline Cinkasse & $\begin{array}{l}-0.11^{*} \\
(0.09)\end{array}$ & $\begin{array}{l}-0.18^{* *} \\
(0.03)\end{array}$ & $\begin{array}{c}3.11 \\
(0.17)\end{array}$ & $\begin{array}{c}0.68 \\
(0.26)\end{array}$ & $\begin{array}{c}0.07^{*} \\
(0.08)\end{array}$ \\
\hline
\end{tabular}

Source: Author's calculation based on data from ANSAT; Numbers in parentheses are p-values; ${ }^{* * *}$ : significant at $1 \%{ }^{* * *}$ significant at $5 \%$; ${ }^{*}:$ significant at $10 \%$.

tion of the prices transmission changes? Is the transmission of a price change from reference market towards dependent markets immediate or delayed? Did the diffusion of the prices at least improve transmission speed of the prices change? To respond to these queries, we carry out the test of causality then analysis the short-term integration.

\subsection{Test for Granger Causality}

The third step is to determine the direction of causality prices interpreted as the direction of the price adjustment between the reference markets (Lome and Atakpame) and dependent markets. The reason for the choice of Lome and Atakpame as the reference markets is as aforementioned, their location respectively in the largest deficit and in the largest surplus regions.

To estimate the model (Equation (12)), we found useful methods to include a number of lags in order to take into account the delay effects due to slow price adjustments in an uncertain environment.

The results in Table 4 show that the direction of the price adjustment process presents a contrast between Lome and Atakpame. Indeed, when considering Atakpame as the reference market, the tests do not indicate a Granger causal effect for the majority of the markets. As for Lome, results are different. The values of the maize prices in Lome contribute significantly to predict prices on all the other markets at 5\%; indicating that Lome plays the role of reference market in the network of markets studied. Consequently, only Lome will be considered in the rest of the analysis.

\subsection{Test for Exogeneity}

The fourth step of the analysis concerns the Hausman endogeneity test called Wu test (Table 5). Following [24], the residues of the auxiliary regression (13) were included as exogenous variable in Equation (14) before per- 
Table 4. Granger causality test with Lome and Atakpame as reference markets.

\begin{tabular}{|c|c|c|c|c|}
\hline \multirow[t]{2}{*}{ Markets } & \multicolumn{2}{|c|}{ Lome } & \multicolumn{2}{|c|}{ Atakpame } \\
\hline & - & - & $F(3,261)$ & 2.19 \\
\hline Lome & $F(2,262)$ & $10.18^{* * *}$ & - & - \\
\hline Sokode & $F(2,262)$ & $7.70^{* * *}$ & $F(3,261)$ & 2.10 \\
\hline Kara & $F(2,262)$ & $6.12^{* * * *}$ & $F(4$ 260) & 2.48 \\
\hline Dapaong & $\mathrm{F}(3,261)$ & $8.20^{* * * *}$ & $F(5,259)$ & $5.15^{* *}$ \\
\hline Amlame & $F(4,260)$ & $5.62^{* *}$ & $F(5,259)$ & $4.31^{* *}$ \\
\hline Anie & $\mathrm{F}(3,261)$ & $7.45^{* * *}$ & $F(4,260)$ & 2.09 \\
\hline Tchamba & $F(2,262)$ & $6.22^{* * *}$ & $F(3,261)$ & 2.23 \\
\hline Sotoboua & $F(2,262)$ & $5.04^{* *}$ & $F(4,260)$ & 2.21 \\
\hline Kabou & $F(4,260)$ & $4.02^{* *}$ & $F(4,260)$ & 2.40 \\
\hline Ketao & $F(5,259)$ & $4.33^{* * *}$ & $\mathrm{~F}(3,261)$ & $4.24^{* *}$ \\
\hline Gando & $F(5,259)$ & $4.00^{* *}$ & $F(5,259)$ & 2.24 \\
\hline Cinkasse & $F(5,259)$ & $4.05^{* *}$ & $F(5,259)$ & 2.65 \\
\hline
\end{tabular}

Source: Author's calculation based on data from ANSAT; ${ }^{* * *}$ : significant at $1 \% ;{ }^{* *}$ : significant at $5 \%$. NB: F $(4,260)$ signifies an $\mathrm{F}$ test with four restrictions and 260 degrees of freedom.

Table 5. Test for endogeneity with Lome as independent market.

\begin{tabular}{ccc}
\hline & Coefficients $\left(\times 10^{-3}\right)$ & T-statistic $\left(\times 10^{-3}\right)$ \\
Atakpame & 6.20 & 3.11 \\
Sokode & -3.95 & -1.12 \\
Kara & -4.56 & -3.05 \\
Dapaong & 1.10 & 2.36 \\
Amlame & 1.10 & 0.24 \\
Anie & 3.41 & 1.32 \\
Tchamba & -2.00 & -6.40 \\
Sotouboua & -1.30 & -0.07 \\
Kabou & 0.18 & 0.17 \\
Ketao & 1.03 & 1.20 \\
Gando & -1.50 & -6.10 \\
Cinkassee & -2.16 & -0.40
\end{tabular}

Source: Author's calculation based on data from ANSAT; NB: All coefficients are significant at $1 \%$.

forming its estimation. Two periods of lag was found sufficient for the robustness and validity of the model. The null hypothesis of independence variable $\Delta R_{1} \quad\left(\mathrm{H}_{0}:=0\right)$ is not rejected at $1 \%$ for all markets, suggesting that OLS will not result in biased estimations.

\subsection{Short Run Markets Integration}

Ravallion model formulated as an error correction mechanism (ECM) is used to simulate the short-term market integration process. The model is estimated by taking the logarithm of the prices. The estimation results are presented in Table 6. Statistically, it appears that the fit ( $\mathrm{R}^{2}$ adj) is relatively low: only $22 \%$ to $46 \%$ of the variation is 
explained. The unexplained variation is due to measurement errors and non-inclusion of non-price variables in the model. In addition, we must not forget that the majority of variables included in the models are estimated in difference, mitigating their effects [30]. However, the estimated ADL models are globally significant (high F statistics). Statistical tests also show no autocorrelation of errors.

In sum, the estimated ADL models are valid and allow obtaining consistent estimators without bias.

Table 6 shows that long-term adjustment prices speeds $\lambda$ represented by the coefficients of $P(-1)$ is significant for all markets but below the ideal value of -1 . For the majority of markets, $\lambda$ is less than 0.50 , indicating that the dysfunction of the maize market, already mentioned by Yovo and Homevoh [2] persists. Dissemination of prices did not improve markets performance.

The second indicator for market functioning is $\beta_{10}$. It is interpreted as the short-term speed of adjustment of prices or the rate of transmission of prices change from the reference market to dependent markets. Analysis of Table 6 shows that for all markets, $\beta_{10}$ is significant and varies between $23 \%$ and $58 \%$. These values are much lower than ideal value of " 1 ". Indicating that instant transmission, that is, during the month, the price change from Lome to dependent markets is low. The price change that occurs in Lome is transmitted with a delay. Indeed, the assumption of the integration of short-term market is rejected at the $5 \%$ level for all markets.

It appears from above that the transmission of price changes from Lome to the dependent markets is not immediate and complete. Although the assumption of short-term integration is rejected, some markets are more integrated than others; therefore it is useful to understand the degree of market integration and price adjustment speed for the period covered by the prices dissemination. The speed of adjustment means the number of days, weeks or months that prices take to complete their adjustment. Dynamic multipliers and the speed of adjustment generated from the ECM are shown in Table 7 below.

The integration index is a composite index and measures the ratio: long-term multiplier/adjustment speed. The long-term multiplier measures the amplitude of the full price adjustment. The average amplitude for the period covered by the dissemination is $45 \%$. The degree of integration is not perfect in the sense that the full adjustment consecutive to prices shock from a price change in Lome market does not reach $100 \%$ for all markets. Meanwhile, the time taken by the price to complete their full adjustment is about 3 months. As a result, the degree of market integration is 0.16 . This index is well below the "ideal" value of 1 and almost identic to the value of 0.15 obtained by Golleti and Babu [25] for maize market in Malawi.

\section{Conclusions, Policy Implication and Orientation for Future Research}

In the framework of liberalization policies, a market information service (SIM) was created in 2008 in Togo.

Table 6. Error correction mechanism with Lome as reference market.

\begin{tabular}{cccccccccc}
\hline Dependent markets & $\lambda$ & $\delta_{\lambda}$ & $\beta_{10}$ & $\delta_{\beta_{10}}$ & $\mathrm{R}^{2}$ adj & $\mathrm{P}(\mathrm{F})$ & $\mathrm{F}_{\mathrm{LM}}$ & $\mathrm{F}_{\text {court1 }}$ \\
\hline Atakpame & $-0.49^{*}$ & 0.04 & $0.58^{*}$ & 0.20 & 0.41 & 0.00 & 0.15 & $56.02^{*}$ \\
Sokode & $-0.38^{*}$ & 0.03 & $0.50^{*}$ & -0.10 & 0.37 & 0.00 & 0.51 & $70.10^{*}$ \\
Kara & $-0.52^{*}$ & 0.20 & $0.52^{*}$ & 0.09 & 0.30 & 0.00 & 0.95 & $38.22^{*}$ \\
Dapaong & $-0.18^{*}$ & -0.2 & $0.31^{*}$ & 0.19 & 0.28 & 0.00 & 1.10 & $31.11^{*}$ \\
Amlame & $-0.32^{*}$ & -0.08 & $0.34^{*}$ & -0.02 & 0.43 & 0.00 & 0.46 & $43.14^{*}$ \\
Anie & $-0.24^{*}$ & -0.16 & $0.22^{*}$ & $0.39^{*}$ & 0.46 & 0.00 & 1.12 & $45.15^{*}$ \\
Tchamba & $-0.35^{*}$ & 0.12 & $0.35^{*}$ & -0.30 & 0.22 & 0.00 & 1.07 & $44.23^{*}$ \\
Sotouboua & $-0.41^{*}$ & 0.06 & $0.38^{*}$ & -0.06 & 0.25 & 0.00 & 0.33 & $64.34^{*}$ \\
Kabou & $-0.29^{*}$ & -0.16 & $0.49^{*}$ & 0.07 & 0.38 & 0.00 & 0.48 & $95.01^{*}$ \\
Ketao & $-0.23^{*}$ & 0.07 & $0.43^{*}$ & 0.02 & 0.40 & 0.00 & 0.07 & $112.13^{*}$ \\
Gando & $-0.30^{*}$ & 0.07 & $0.23^{*}$ & -0.43 & 0.44 & 0.00 & 0.05 & $78.60^{*}$ \\
Cinkasse & $-0.52^{*}$ & 0.11 & $0.34^{*}$ & $0.06^{*}$ & 0.29 & 0.00 & 0.90 & $88.50^{*}$ \\
\hline
\end{tabular}

Source: Author's calculation based on data from ANSAT; The asterisks $\left({ }^{*}\right)$ indicate a significant value at $5 \%$. F short means short run integration test: Ho: $\beta_{10}=1 ; \lambda=1$ and $\alpha_{11}=\cdots=\alpha_{i 1}=\beta_{11}=\cdots=\beta_{1 n} ; \mathrm{F}_{\mathrm{LM}}$, autocorrelation test. No rejection of the null hypothesis. 
Table 7. Long term multipliers, adjustment speed, integration index.

\begin{tabular}{cccc}
\hline & Long term multipliers & Adjustment speed & Integration index \\
\hline Atakpame & 0.81 & 2 & 0.41 \\
Sokode & 0.82 & 3 & 0.27 \\
Kara & 0.75 & 2 & 0.38 \\
Dapaong & 0.23 & 3 & 0.08 \\
Amlame & 0.3 & 3 & 0.10 \\
Anié & 0.2 & 2 & 0.10 \\
Tchamba & 0.41 & 3 & 0.14 \\
Sotouboua & 0.32 & 4 & 0.08 \\
Kabou & 0.06 & 4 & 0.02 \\
Ketao & 0.42 & 3 & 0.14 \\
Gando & 0.35 & 4 & 0.09 \\
Cinkasse & 0.75 & 1 & 0.75 \\
Moyenne & 0.45 & 2.83 & 0.16 \\
\hline
\end{tabular}

Source: Author calculation with data from ANSAT; NB: The values of long term multipliers, adjustment speed and integration index are all significant at $5 \%$

This public service entrusted in collecting and disseminating information about the mercurial of agricultural products aimed to improve the spatial integration of agricultural markets through the development of arbitrage. This paper assesses to what extent the existence of this service contributed to the spatial integration of maize markets.

The results show that the impact of price dissemination on the spatial integration of maize markets is mitigated. By reference to Lome, neither rural markets nor northern markets have significantly improved their level of long-term and short-term spatial integration. The prices diffused by the information service do not really contribute to improve the arbitrage process of maize traders. This moderate impact can be explained by the quasi-general ignorance about the existence and the utility of the information service.

For example, very few traders and mainly farmers know the day and the time of price dissemination on national television channel. Also, very few have access to television and new information and communication technologies. Moreover, the messages broadcast in French are not well understood by many actors, most of whom are illiterate. Usually, the information disseminated already exists through the use of mobile phones or through traditional communication channels. In which case, the current format of information service appears not to be relevant.

These results invite the Togolese authorities to improve the efficiency of the diffusion of information system. This implies that the delivery method of the mercurial should rather be improved and there should be more information collected and disseminated.

Specifically:

- There should be more information collected and disseminated regarding the prices, the conditions of market demand and supply for each economic region of the country;

- There should be price difference's data dissemination for each local market as well as the difference price's data with the neighboring countries, in a way that the exporters could be aware of their business opportunities.

- The information release frequency should be increased (for example, twice a week) with the use of the available media such as rural radio stations that communicate in local languages.

These suggestions are not solely enough to increase the efficiency of the information service. There are other constraints that hamper the effectiveness of market integration. Indeed, despite the liberalization, the government through ANSAT continues to regulate cereals markets by buying and selling over the country. This public intervention is badly appreciated by traders and is a source of discouragement because it restricts trade with neighboring countries. So arbitrage opportunities are limited due to the thinness of local market. And as the 
quantities sold are relatively low, traders are not motivated to invest in the acquisition of information. Therefore, improving the efficiency of the operation of cereals markets also requires institutional innovation.

These recommendations, even relevant, are not enough to anticipate their impact in term of improving the efficiency of information service. An investigation is necessary to understand the need of the sector's stakeholders. This understanding should be supported by detailed surveys to determine the actual needs and information requirements of market participants. Such surveys can cover farmers, wholesalers, retailers, brokers and traders, exporters, extension services, government departments, and even consumers. The surveys will identify:

- the exact type of information each market participant requires;

- the format in which such information should be presented;

- the method or media choice for dissemination;

- how often information should be provided;

- at what time of day information should be disseminated;

- whether any market participants will require extension services or other education to ensure that they can understand and utilize information effectively.

\section{References}

[1] Bassolet, B. and Lutz, C. (1998) Service d'information et d'intégration des marchés céréaliers au Burkina-Faso. Revue d'Economie du Développement, 6, 45-66.

[2] Yovo, K. and Homevoh, E. (2006) Libéralisation du commerce et intégration spatiale des marchés: le cas du maïs au Togo. Revue Africaine de Développement, 18, 1-29.

[3] Lucas, R. (1972) Expectations and the Neutrality of Money. Journal of Economic Theory, 4, 103-124. http://dx.doi.org/10.1016/0022-0531(72)90142-1

[4] Green, J.R. (1973) Information, Efficiency and Equilibrium. Discussion Paper No. 284, Harvard Institute of Economic Research, Harvard University, Cambridge.

[5] Garcia, R. (1986) La théorie économique de l'information: Exposé synthétique de la littérature. L’Actualité Economique, Revue d'analyse economique, 62, 88-109.

[6] Laffont, J.J. (1985) Economie de l'incertain et de l’information, Cours de théorie microéconomique, Vol. 2. Economica, Paris.

[7] Grossman, S.J. and Stiglitz, J.E. (1976) Information and Competitive Price Systems. American Economies Review, 66, 246-253.

[8] Stiglitz, J. (1991) Rational Peasants, Efficient Institutions and a Theory of Rural Organization; Methodological Remarks for Development Economics. In: Bardhan, P., Ed., The Economic Theory of Agrarian Institutions (Clarendon Paperbacks), Oxford University Press, Oxford, 18-29.

[9] Akerlof, G. (1970) The Market for “Lemons”: Qualitative Uncertainty and Mechanism. Quarterly Journal of Economics, 84, 488-500. http://dx.doi.org/10.2307/1879431

[10] Shepherd, A. (1997) Market Information Services: Theory and Practice. FAO Agricultural Services Bulletin, Food and Agriculture Organization of the United Nations, Rome,1-28.

[11] Egg, J. (2005) Systèmes d'informations sur les marchés: Est-ce utile? Pour qui? Pour quoi? Compte rendu de la $9^{\mathrm{e}}$ conférence des «Mardis du Baume» tenue le 05 avril 2005 à, ISRA-Bel Air, Sénégal.

[12] Galtier, F. and Egg, J. (2003) Le paradoxe des systèmes d'information de marché (SIM): Une clef de lecture issue de l'économie institutionnelle et de la théorie de la communication. Working Paper UMR/MOISA, Montpellier.

[13] Dembele, N. and Staatz, J. (1990) Les systèmes d’information sur les marchés céréaliers, l’expérience du Mali. Séminaire, Bamako.

[14] Spore (1997) Systèmes d'information de marché: Mobiliser le secteur privé. Bulletin du CTA, 69, 1-3.

[15] Barrett, C. (1996) Market Analysis Methods: Are Our Enriched Toolkits Well Suited to Enlivened Market? American Journal of Agricultural Economics, 78, 825-829. http://dx.doi.org/10.2307/1243313

[16] Barrett, C., Li, J.R. and Bailey, D.V. (2000) Factors and Product Market Tradability and Equilibrium in Pacific Rim Pork Industries. Journal of Agricultural and Resource Economics, 25, 68-87.

[17] Mc New, K. (1996) Spatial Market Integration: Definition, Theory and Evidence. Agricultural and Resource Economics Review, 25, 1-11.

[18] Mc New, K. and Fackler, P.L. (1997) Testing Market Equilibrium: Is Cointegration Informative? Journal of Agricultural and Resource Economics, 22, 191-207. 
[19] Baulch, B. (1997) Transfer Costs, Spatial Arbitrage, and Testing for Food Market Integration. American Journal of Agricultural Economics, 79, 477-487.

[20] Li, J.R. and Barett, C.B. (1999) Distinguishing between Equilibrium and Integration in Market Analysis. Proceedings of the 1999 Annual Meeting of American Agricultural Economic Association, Nashville, 8-11 August 1999, 1-20.

[21] Ravallion, M. (1986) Testing Market Integration. American Journal of Agricultural Economics, 68, 102-109. http://dx.doi.org/10.2307/1241654

[22] Banerjee, A., Dolado, J., Galbraith, W. and Hendry, F. (1993) Cointegration, Error-Correction and the Econometric Analysis of None-Stationary Data. Advanced Text in Econometrics, Oxford University Press, Oxford.

[23] Engle, R. and Granger, C.J. (1987) Co-Integration and Error Correction: Representation, Estimation, and Testing. Econometrica, 55, 251-276. http://dx.doi.org/10.2307/1913236

[24] Dercon, S. (1995) On Market Integration and Liberalisation: Method and Application to Ethiopia. Journal of Development Studies, 32, 112-143.

[25] Golleti, F. and Babu, S. (1994) Market Liberalization and Integration of Maize Markets in Malawi. Agricultural Economics, 11, 311-324.

[26] Mohammad, I. and Andrew, P. (1998) Government Intervention and Market Integration in Indonesian Rice Markets. Agricultural Economics, 19, 283-295.

[27] Rashid, S. (2004) Spatial Integration of Maize Markets in Post-Liberalised Uganda. Journal of African Economies, 13, 102-133. http://dx.doi.org/10.1093/jae/13.1.102

[28] Jha, R.K., Murthy, V.B. and Sharma, A. (2005) Market Integration in Wholesale Rice Markets in India. ASARC Working Paper 2005/03.

[29] Pindyck, R. and Rubinfeld, D. (1991) Econometric Models and Econometric Forecasts. Mac Graw-Hill, New York.

[30] Lutz, C.H.M. (1994) The Functioning of the Maize Market in Benin: Spatial and Temporal Arbitrage on the Market of a Staple Food Crop. Ph.D. Thesis, Department of Regional Economics, University of Amsterdam, Amsterdam. 
Annex 1: Graphic of Price Series on Studied Markets with Lome as Reference
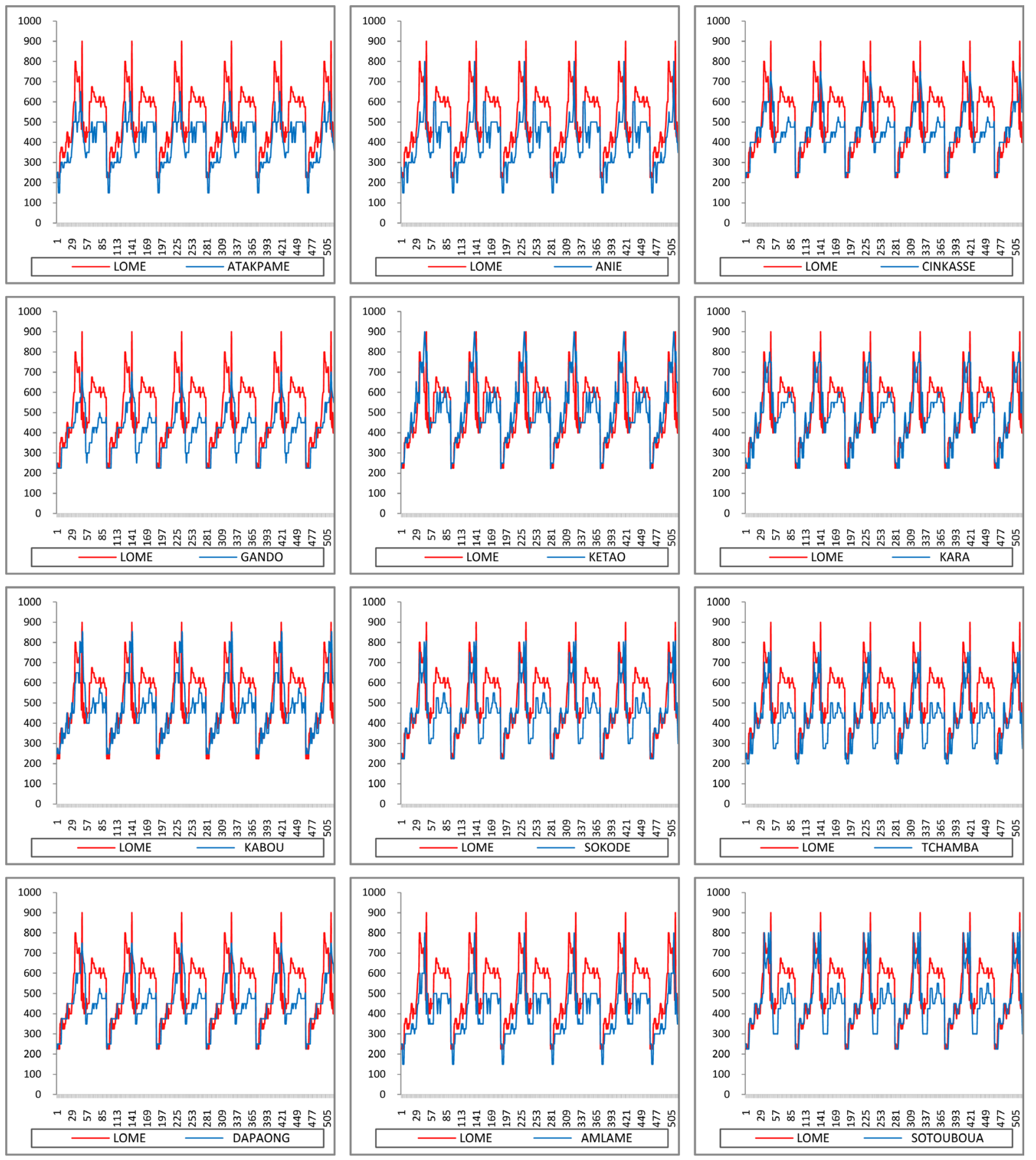


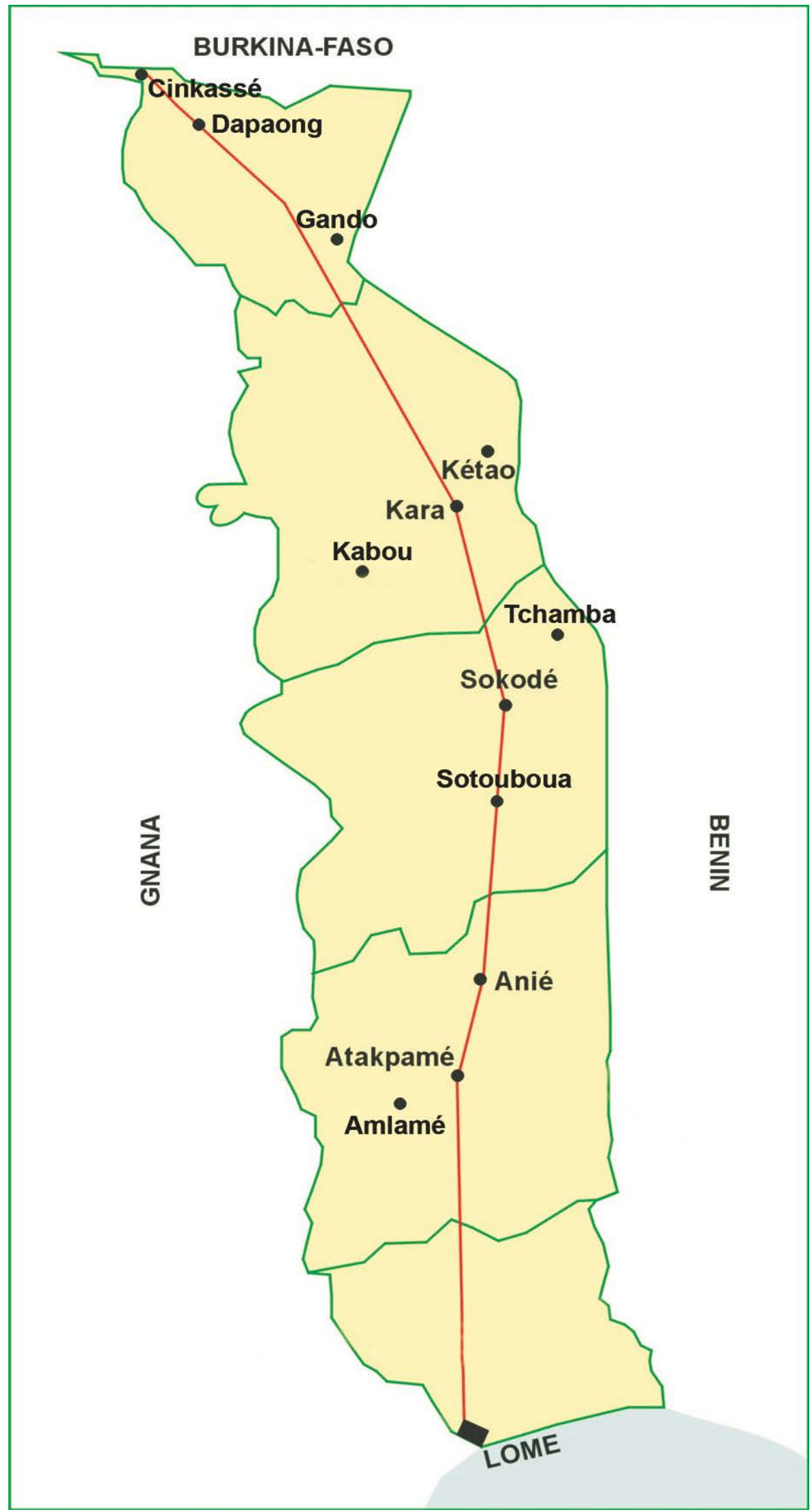


Scientific Research Publishing (SCIRP) is one of the largest Open Access journal publishers. It is currently publishing more than 200 open access, online, peer-reviewed journals covering a wide range of academic disciplines. SCIRP serves the worldwide academic communities and contributes to the progress and application of science with its publication.

Other selected journals from SCIRP are listed as below. Submit your manuscript to us via either submit@scirp.org or Online Submission Portal.
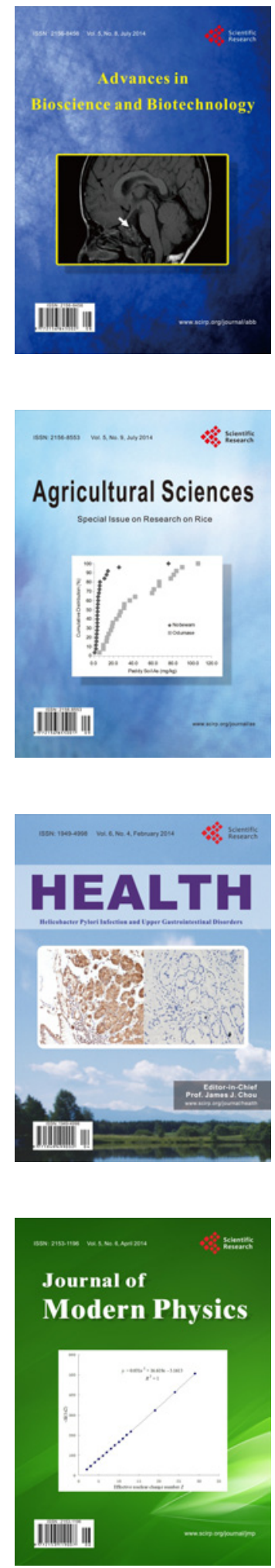
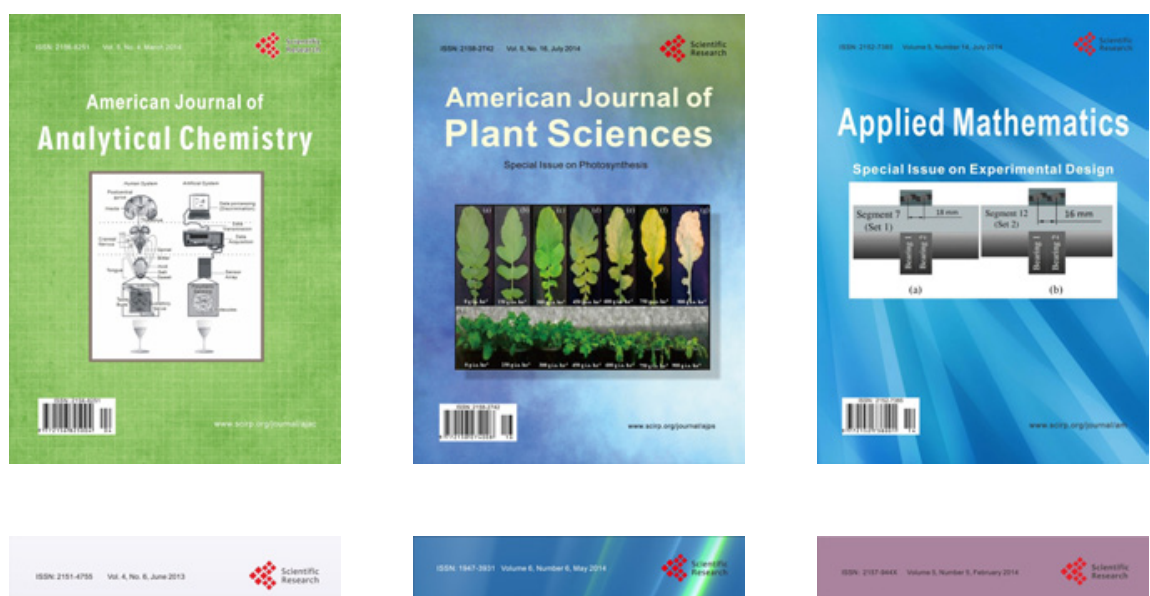

Creative Education
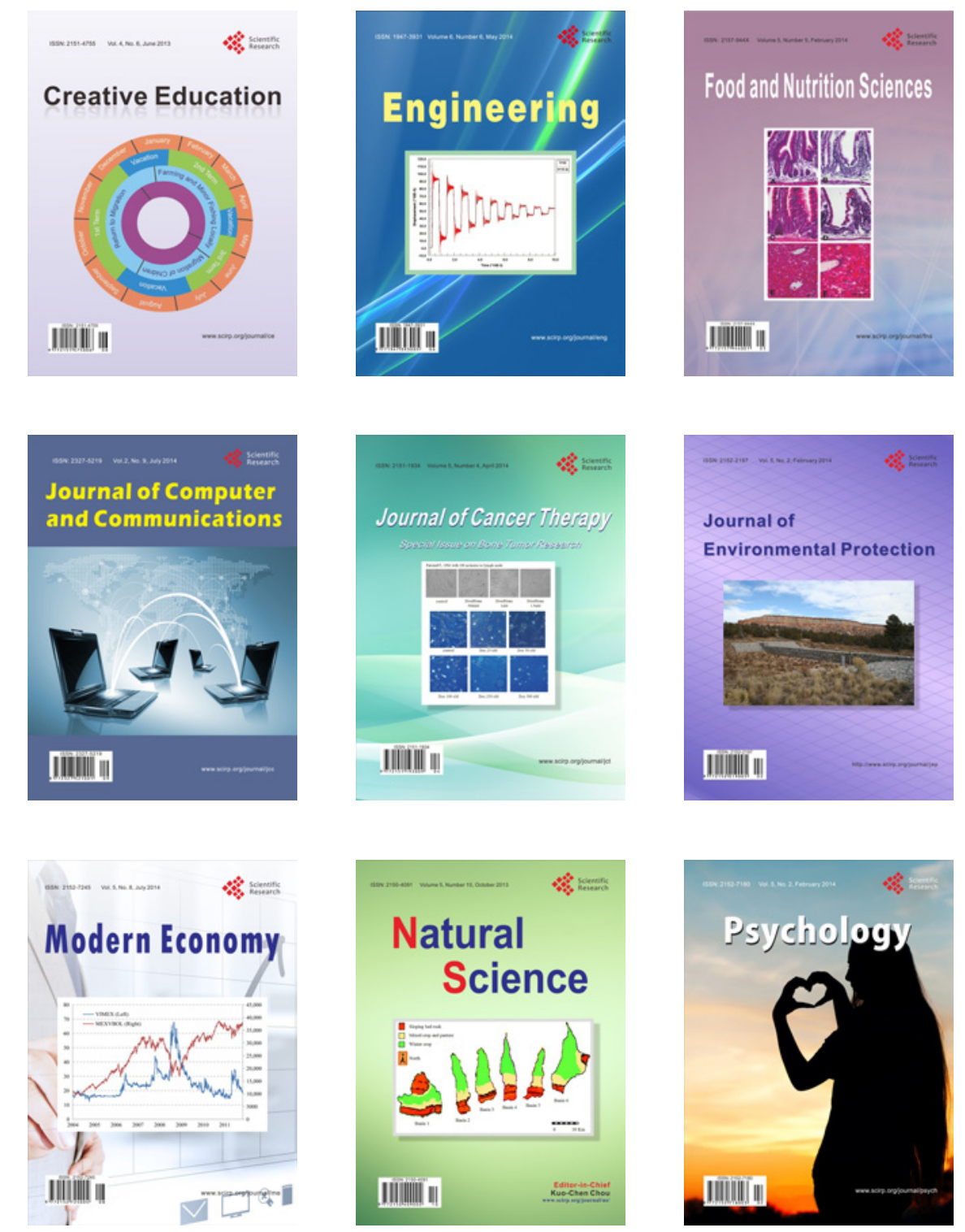